\title{
Physical and sensorial properties of potato breads fortified with whole soybean flour
}

\section{Propridades físicas e sensoriais de pães de batata fortificados com farinha integral de soja}

\begin{abstract}
The aim of this work was to study the effects of fortification of potato bread with whole soybean flour on their physicochemical and sensory properties. Control formulations containing 30\%, 50\% and $70 \%$ soybean flour were developed. Firmness, cohesiveness, gumminess and chewiness of bread increased with the addition of whole soybean flour. The contents of protein, dietary fiber and minerals calcium, zinc, magnesium, copper and phosphorus increased with elevated concentration of soybean flour, while the lipid profile was unchanged. Preference mapping indicated greater acceptance of the control and $30 \%$ whole soybean flour formulations. These results were correlated to texture and showed that the greater firmness negatively affected its acceptance. It was concluded that the formulation with $30 \%$ was the best option offering good acceptance and high content of nutrients, which makes the flour substitution a viable alternative for the preparation of fortified baking products with equal sensory and physicochemical quality.

Key words: functional ingredients; chemical composition; sensory acceptance; Internal Preference Mapping; physicochemical properties.
\end{abstract}

\section{INTRODUCTION}

The development of fortified foods has been an important aspect of food research due to the increasing consumer interest in products that can claim high nutritional value and functional properties (1-3). Breads are traditional foods consumed throughout the entire world. The potato breads are a variation of the traditional breads (4) and just as it presents pleasant aromas and flavors, low price and wide availability in most food markets which contribute to high consumption rates $(5,6)$. Despite their popularity, most breads possess a low concentration of micronutrients and elevated levels of carbohydrates compared to other foods because their main ingredient is refined wheat flour $(5,7)$.

Alternatives to these traditional recipes include the full or partial replacement of refined wheat flour with ingredients exhibiting higher nutrient content. However, this may have an immediate impact on the ability to maintain desired sensory characteristics of the finished bread product which are crucial to ensure consumer acceptance and consumption of these products. Studies indicate that the replacement of refined wheat flour with flours containing high levels of dietary fiber and lacking gluten in bakery products results in a tougher
Dorina Isabel Gomes Natal (1)

Maria Inês de Souza Dantas (1)

Márcia Cristina Teixeira Ribeiro Vidigal (2)

Sônia Machado Rocha Ribeiro (1)

Roberta Ribeiro Silva (3)

Hércia Stampini Duarte Martino (1)

(1) Departamento de Nutrição e Saúde (DNS), Universidade Federal de Viçosa (UFV), Viçosa, MG, Brazil. (2) Departamento de Tecnologia de Alimentos, Universidade Federal de Viçosa (UFV), Viçosa, MG, Brazil. (3) Departamento de Nutrição, Universidade Federal de Alfenas (UNIFAL-MG), Alfenas, MG, Brazil.

Correspondence to the author: Professor

Hércia Stampini Duarte Martino Departamento de Nutrição e Saúde (DNS) Campus Universitário S/N, Universidade Federal de Viçosa (UFV), Viçosa, MG, 36 Fax: 55 (031) 3899-2541 E-mail: hercia@ufv.br

Este trabajo fue recibido el 7 de Agosto de 2012 y aceptado para ser publicado el 18 de Enero de 2013.

dough texture and alterations to the flavor that decrease acceptance $(3,8,9)$.

The soybean is a legume of significant interest to food and nutrition professionals as it offers several nutrients including protein, dietary fiber, essential fatty acids, vitamins and minerals $(1,10)$. Additionally, soybean contains bioactive compounds such as isoflavones, which have been shown to aid in the prevention of non-communicable diseases such as diabetes (11), osteoporosis (12), dyslipidemia (11) as well as exhibit antioxidant activity (13). However, soybean contains lipoxygenases which cause processed food products containing soy to have a bean flavor that restricts consumption of these products. To overcome this problem and increase soybean consumption, lipoxygenase-free cultivars with improved flavor are being developed $(2,10)$.

Several studies have investigated the development of bakery products formulated with partial replacement of wheat flour with soybean flour in order to add nutritional value $(1-3,6)$. However, current studies do not demonstrate ability to maintain sensory quality as soybean flour replaces wheat flour and no relationship has been made between physical parameters and sensory acceptance. The aim of 
this work was to study the effects of fortification of potato bread with whole soybean flour on physicochemical and sensory properties.

\section{MATERIALS AND METHODS Materials}

For the preparation of whole soybean flour, the new cultivar UFVTN 105AP, developed by the Soybean Breeding Program of the Biotechnology Institute of the Universidade Federal de Viçosa (BIOAGRO/ UFV), was prepared using a backcrossing method. The cultivar from the 2009 harvest, developed without the three isoforms of enzyme lipoxygenases (LOX1, LOX2 and LOX3), has high protein content (14).

\section{Methods}

Preparation of whole soybean flour

Soybeans were selected, washed, and dried at room temperature and subjected to heat treatment at $150^{\circ} \mathrm{C}$ for 30 minutes in an oven with air circulation (New Ethics 400/6ND (B) model, Vargem Grande Paulista, Sao Paulo, Brazil). Grains were ground in a rotor mill (Marconi ${ }^{\circledR}$ model 090/CFT MA, Piracicaba, São Paulo, Brazil) with a 30 mesh sieve. The resulting flour was stored in polyethylene bags at $-22^{\circ} \mathrm{C}$ for later use in the development of potato breads.

\section{Development of potato bread}

The breads were made from a control formulation and the concentrations of whole soybean flour were defined according to the preliminary tests. Four formulations were developed containing $0 \%, 30 \%, 50 \%$ and $70 \%$ whole soybean flour to partially replace refined wheat flour (table 1). The amount of soybean oil added to the formulations varied according to the concentration of lipids in the whole soybean flour (14). The amount of milk added increased proportionally with the addition of soybean flour in order to compensate for increased fluid absorption by the dough with higher protein content (15).

To develop the potato bread, yeast was dissolved in a mixture of milk heated to $30^{\circ} \mathrm{C}$ and $30 \mathrm{~g}$ of wheat flour. This mixture was covered with polyethylene film for 15 minutes at room temperature. Next, sugar, salt, egg, oil and potatoes were mixed in a blender, followed by the addition of activated yeast. The wheat and soybean flours were slowly added until smooth dough was formed. This was left to stand at room temperature for 20 minutes to stimulate the fermentation process. Subsequently, the dough was distributed into $30 \mathrm{~g}$ serving size, round portions and baked in a conventional gas oven (Dako, Top Model Grill, Campinas, Sao Paulo, Brazil) at $180^{\circ} \mathrm{C}$ for 10 minutes.

The potato breads were prepared in a single lot for analysis. The samples were prepared and stored in polyethylene bags at room temperature one day before the sensory tests and texture profile, then stored in polyethylene bags at $-22^{\circ} \mathrm{C}$ for chemical analysis. One repetition for the sensory test was completed while three repetitions for the texture profile and chemical analysis were done.

Texture profile analysis (TPA)

The potato bread samples were subjected to TPA com-

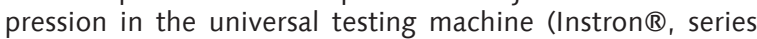
3367, United Stated). A $50 \mathrm{~mm}$ diameter probe was moved perpendicularly over the spherically shaped potato bread samples with a diameter of $45 \mathrm{~mm}$ and height of $30 \mathrm{~mm}$. Working conditions included a compression distance of $40 \%$ of the sample height and speed of $1.7 \mathrm{~mm} / \mathrm{s}$ with two compression cycles (16).

The force exerted on the samples was automatically recorded and the firmness $(\mathrm{N})$, cohesiveness (dimensionless), gumminess $(\mathrm{N})$, chewiness $(\mathrm{J})$ and springiness $(\mathrm{mm})$ parameters were evaluated automatically from the force $(N) \times$ time (s) curves generated during the test by the Blue Hill software 2.0 (Instron ${ }^{\circledR}$, series 3367, United Stated). Three repetitions were performed for each sample with five readings for each repetition.

\section{Chemical analysis}

Moisture, protein, lipid and ash analyses were performed according to AOAC (17), the soluble and insoluble dietary fibers were determined by enzymatic gravimetric method, as reported in the methodology proposed by AOAC (18), and carbohydrate content was calculated as the difference (19). The caloric value was calculated by summing the ca-

\section{TABLE 1}

Formulations of potato bread $\left(\mathrm{g} \cdot 100 \mathrm{~g}^{-1}\right)$.

Ingredients

Yeast

Refined wheat flour

Granulated sugar

Refined salt

Soybean oil

Chicken egg

Cooked potato

Refined wheat flour

Whole soybean flour
13,2

3,1

3,8

2,8

0,6

6,6

7,2

15,7

47,0
Formulations

F2

14,1

3,2

3,8

2,9

0,6

4,2

7,3

16,0

33,5

14,4
F3

15,9

3,2

3,8

2,9

0,6

2,5

7,3

16,0

23,9

23,9
F4

17,8

3,2

3,8

2,8

0,6

0,9

7,3

15,9

14,3

33,4

F1= Control formulation; F2 = Formulation with $30 \%$ whole soybean flour;

F3 = Formulation with $50 \%$ whole soybean flour; F4 = Formulation with $70 \%$ whole soybean flour. 
lories supplied by proteins, carbohydrates and lipids using the conversion factors 4 kcal.g-1, 4 kcal.g-1, and 9 kcal.g-1, respectively (19).

The analysis of minerals was performed by digestion in nitric acid followed by measurement with an atomic absorption and flame spectrophotometer according to the mineral analysis protocol (20). Fatty acids were quantified by gas chromatography $(21,22)$.

\section{Sensory analysis}

The sensory evaluation of these potato breads was performed in a supermarket in the city of Viçosa, Brazil. Acceptability tests were previously approved by the ethics committee of the Federal University of Viçosa, protocol number 101/2009.

Potato bread samples weighing approximately $7 \mathrm{~g}$ were identified with a three-digit code and presented to consumers individually, according to the randomized block design. Participating in this study were 102 consumers of both sexes including 32 men and 70 women.

Consumers rated the overall acceptability of the formulations using a nine point hedonic scale (23) and responded to an evaluation of their intention to purchase the products.

\section{Statistical analysis}

The effect of adding soybean flour to potato bread dough on the instrumental texture parameters and on the sensory characteristics was evaluated using the techniques of Analysis of Variance (ANOVA) and Principal Component Analysis (PCA).

The sensory responses were assessed by the Internal Preference Mapping methodology (24). Sensory evaluation data were then organized in a matrix of samples (in lines) and consumers (in columns) and the covariance matrix was evaluated. The results were expressed as scatter plots of samples and individual consumers in relation to the first two principal dimensions.

The chemical composition data were analyzed by the ANOVA following to the post hoc test, Tukey at 5\% probability, with the exception of dietary fiber, fat acids and carbohydrates.

Analyses of the correlations (Pearson) were performed between the instrumental texture parameters and the principal components obtained from PCA of sensorial acceptability data (25)

All statistical analyses were performed using the Statistical Analysis System (SAS), version 9.1 (2009) licensed for use by the Federal University of Viçosa.

\section{RESULTS}

Texture profile analysis (TPA)

The addition of whole soybean flour to potato breads increased $(p<0.05)$ the parameters of firmness, cohesiveness, gumminess and chewiness. In regards to springiness, there was no change $(p>0.05)$ for the different concentrations of whole soybean flour (table 2).

Correlation of texture parameters and the spatial arrangement of samples in relation to the first two principal components were illustrated in figure 1. The parameters were represented by vectors and the distance between each vector and the $\mathrm{x}$ or $\mathrm{y}$ axis represents the linear correlation between the parameter and the respective component.

The first principal component explained $99.99 \%$ of the total variation in the data, being sufficient to discriminate the formulations. Spatial arrangement of potato bread samples for the first principal component suggests that the control and 30\% and 50\% whole soybean flour formulations formed a group that differs from the formulation with $70 \%$ in regards to the instrumental texture parameters. Firmness, cohesiveness, gumminess and chewiness were positively correlated $(p<0.04)$ with only the first principal component, demonstrating that the formulation containing $70 \%$ whole soybean flour, located to the right in figure 1, had a higher intensity of these parameters. The second major component is associated with the springiness parameter $(r=-0.87)$. Since only $0.01 \%$ of total variation of the data was explained by this component, all samples were similar with respect to this attribute.

\section{Chemical analyses}

The increase in concentration of whole soybean flour increased the protein content in the formulations $(p<0.05)$ (table 3). This trend was also observed for levels of total dietary fiber and the soluble and insoluble fractions.

Moisture of the breads increased $(p<0.05)$ and there was no difference in lipid concentration $(p>0.05)$. The carbohydrate content of the preparations was reduced by about $20 \%$ depending on the concentration of whole soybean flour in the potato breads.

The potato breads to which whole soybean flour was added showed high $(p<0.05)$ levels of calcium, zinc, magnesium, copper and phosphorus (table 3 ). Sodium and potassium contents remained unchanged as did fatty acid composition (table 4).

\section{TABLE 2}

Texture properties of potato bread formulations.

\begin{tabular}{cccccc}
\hline Formulations & $\begin{array}{c}\text { Firmness } \\
(\mathrm{N})\end{array}$ & $\begin{array}{c}\text { Cohesiveness } \\
\text { (dimensionless) }\end{array}$ & $\begin{array}{c}\text { Springiness } \\
(\mathrm{mm})\end{array}$ & $\begin{array}{c}\text { Gumminess } \\
(\mathrm{N})\end{array}$ & $\begin{array}{c}\text { Chewiness } \\
(\mathrm{J})\end{array}$ \\
& & & & \\
$\mathrm{F} 1$ & $14^{\mathrm{b}} \pm 0.93$ & $0.90^{\mathrm{b}} \pm 0.01$ & $9.3^{\mathrm{a}} \pm 0.66$ & $8.3^{\mathrm{b}} \pm 0.4$ & $93^{\mathrm{b}} \pm 7.8$ \\
F2 & $16^{\mathrm{b}} \pm 2.2$ & $0.90^{\mathrm{b}} \pm 0.01$ & $9.2^{\mathrm{a}} \pm 1.20$ & $9.3^{\mathrm{b}} \pm 1.5$ & $99^{\mathrm{b}} \pm 4.8$ \\
F3 & $23^{\mathrm{b}} \pm 3.4$ & $0.91^{\mathrm{ab}} \pm 0.00$ & $9.0^{\mathrm{a}} \pm 0.97$ & $13^{\mathrm{b}} \pm 1.6$ & $147^{\mathrm{b}} \pm 23$ \\
F4 & $40^{\mathrm{a}} \pm 7.3$ & $0.92^{\mathrm{a}} \pm 0.01$ & $9.4^{\mathrm{a}} \pm 0.09$ & $24^{\mathrm{a}} \pm 4.5$ & $27^{\mathrm{a}} \pm 53$
\end{tabular}

F1 = Control formulation; F2 = Formulation with 30\% whole soybean flour; F3 = Formulation with 50\% whole soybean flour;

F4 = Formulation with $70 \%$ whole soybean flour.

Means followed by same letter in the same row do not differ by Tukey test, a $5 \%$ probability. 


\section{FIGURE 1}

Principal Component Analysis of texture parameters of the formulations of potato bread.

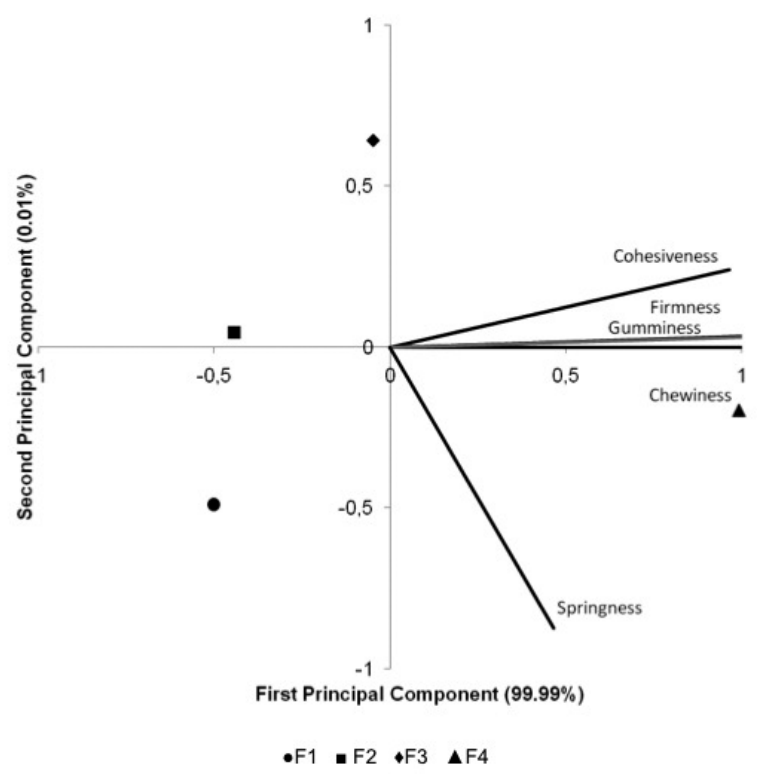

$\mathrm{F} 1=$ Control formulation; F2 = Formulation with $30 \%$ whole soybean flour; F3 = Formulation with $50 \%$ whole soybean flour; F4 = Formulation with $70 \%$ whole soybean flour.

\section{TABLE 3}

Chemical composition proximate $\left(\mathrm{g} \cdot 100 \mathrm{~g}^{-1}\right)$, caloric value $(\mathrm{Kcal})$ and minerals $\left(\mathrm{mg} \cdot 100 \mathrm{~g}^{-1}\right)$ of potato breads.

\begin{tabular}{|c|c|c|c|c|}
\hline & \multicolumn{4}{|c|}{ Formulations } \\
\hline & $\mathrm{F} 1$ & $\mathrm{~F} 2$ & F3 & $\mathrm{F} 4$ \\
\hline Moisture & $31^{c} \pm 0.35$ & $33^{b} \pm 0.09$ & $33^{b} \pm 0.02$ & $36^{a} \pm 0.36$ \\
\hline Protein & $9.6^{d} \pm 0.08$ & $14^{c} \pm 0.01$ & $17^{b} \pm 0.40$ & $21^{a} \pm 0.36$ \\
\hline Lipid & $6.8^{a} \pm 0.04$ & $6.6^{a} \pm 0.07$ & $6.4^{a} \pm 0.21$ & $6.9^{a} \pm 0.21$ \\
\hline Ash & $1.4^{c} \pm 0.06$ & $2.2^{b c} \pm 0.12$ & $2.9^{\mathrm{ab}} \pm 0.25$ & $3.9^{a} \pm 0.39$ \\
\hline Carbohydrate & 49 & 38 & 33 & 25 \\
\hline TDF & 2.4 & 5.5 & 6.5 & 7.1 \\
\hline IDF & 1.6 & 4.8 & 5.9 & 6.6 \\
\hline SDF & 0.80 & 0.74 & 0.59 & 0.47 \\
\hline Caloric value & 295 & 269 & 261 & 246 \\
\hline Iron & $7.3^{a} \pm 0.23$ & $6.2^{\mathrm{ab}} \pm 0.30$ & $5.9^{\mathrm{ab}} \pm 0.18$ & $5.6^{b} \pm 0.38$ \\
\hline Calcium & $33^{c} \pm 1.2$ & $54^{b} \pm 3.7$ & $72^{a} \pm 1.8$ & $84^{a} \pm 2.8$ \\
\hline Zinc & $1.3^{c} \pm 0.04$ & $1.9^{b} \pm 0.00$ & $2.3^{\mathrm{ab}} \pm 0.12$ & $2.7^{a} \pm 0.12$ \\
\hline Manganese & $0.67^{b} \pm 0.04$ & $0.87^{\mathrm{ab}} \pm 0.00$ & $0.88^{\mathrm{ab}} \pm 0.07$ & $1.0^{a} \pm 0.04$ \\
\hline Magnesium & $34^{c} \pm 0.41$ & $66^{\mathrm{b}} \pm 1.4$ & $83^{b} \pm 7.2$ & $117^{a} \pm 0.72$ \\
\hline Sodium & $332^{a} \pm 23$ & $343^{\mathrm{a}} \pm 8.8$ & $492^{\mathrm{a}} \pm 122$ & $591^{a} \pm 221$ \\
\hline Potassium & $256^{a} \pm 15$ & $545^{a} \pm 12$ & $745^{\mathrm{a}} \pm 7.5$ & $958^{a} \pm 4.0$ \\
\hline Copper & $0.09^{c} \pm 0.01$ & $0.24^{b c} \pm 0.00$ & $0.35^{\mathrm{ab}} \pm 0.04$ & $0.48^{a} \pm 0.06$ \\
\hline Phosphorus & $113^{c} \pm 6.7$ & $209^{b} \pm 19$ & $247^{\mathrm{ab}} \pm 9.8$ & $309^{a} \pm 5.6$ \\
\hline
\end{tabular}




\section{Sensory analysis}

The frequency of the scores assigned to the potato bread formulations, according to the opinion of consumers, is presented in table 5 .

All formulations were well accepted, with the majority of scores above 6 on the hedonic scale. However, there was greater acceptance of the control and with 30\% whole soybean flour formulations which had a higher frequency of grades 7 and 8 .

The ANOVA of consumer responses reveals significant differences between consumers; however, the mean score values for the four formulations showed little variation, indicating that there was a variety of responses to each formulation. Therefore, standardization of the data was carried out by Internal Preference Mapping.

The Internal Preference Mapping of all consumer data showed that about $78.7 \%$ of the variation in the preferences was explained by the first two principal components, sufficiently high to discriminate difference among the formulations (figure 2). The first principal component explained $51 \%$ of the total variation of data and the second explained $27.7 \%$.

The spatial arrangement of the samples suggests the formation of four distinct groups, one for each formulation of potato bread. Each point represents the correlations between data from consumer acceptance and the first two principal components. Consumers closest to the center of the chart did not correlate with either of the two principal components and contributed little to the discrimination of the formulations. These are considered to have presented similar acceptance. The concentration of consumers positively correlated with the first principal component indicated a greater acceptance of the control and formulation with $30 \%$ whole soybean flour.

The four potato bread formulations presented good intention to purchase as about $70 \%$ of panelists $(n=83, n=77, n=70$ and $n=64$, respectively) indicated they would buy the products.

Correlation of instrumental texture parameters with the sensory acceptability

The correlation analysis (Pearson) between texture parameters and the first two principal components obtained from PCA of acceptance data indicated the instrumental texture characteristics are responsible for differences in the acceptance of potato bread formulations (figure 3 ). The texture characteristics were represented by vectors and consumers by the points.

The first principal component explained $98.7 \%$ of the

\section{TABLE 4}

Fatty acid composition of potato breads (g-100g-1) and $\omega-6 / \omega-3$ ratio.

\begin{tabular}{|c|c|c|c|c|}
\hline & \multicolumn{4}{|c|}{ Formulations } \\
\hline & $\mathrm{F} 1$ & $\mathrm{~F} 2$ & F3 & $\mathrm{F} 4$ \\
\hline Palmitic & 0.91 & 0.85 & 0.74 & 0.83 \\
\hline Stearic & 0.29 & 0.28 & 0.26 & 0.30 \\
\hline Oleic & 1.8 & 1.6 & 1.6 & 1.6 \\
\hline Linoleic $(\omega-6)$ & 3.4 & 3.5 & 3.5 & 3.7 \\
\hline$\alpha-$ linoleic acid $(\omega-3)$ & 0.37 & 0.41 & 0.32 & 0.39 \\
\hline$\omega-6 / \omega-3$ ratio & 9.3:1 & $8.5: 1$ & $11: 1$ & $9.5: 1$ \\
\hline
\end{tabular}

F1 = Control formulation; F2 = Formulation with 30\% whole soybean flour; F3 =Formulation with 50\% whole soybean flour;

F4 = Formulation with $70 \%$ whole soybean flour.

TABLE 5

Frequencies of scores at nine hedonic terms, for the formulations of potato bread.

Terms hedonic

$\begin{array}{cc}\text { Grades } & F \\ 9 & 14 \\ 8 & 3 \\ 7 & 2 \\ 6 & 1 \\ 5 & 4 \\ 4 & 4 \\ 3 & 2 \\ 2 & 0 \\ 1 & 1\end{array}$

F1

14

Like extremely

Like very much

Like moderately

Like slightly

Neither like or dislike

Dislike slightly

Dislike moderately

Dislike very much

Dislike extremely

1
4
5
9
3
4
4
2
0
1

Formulations

F2 F3

F3 F4

$\begin{array}{lll}7 & 9 & 10\end{array}$

$34 \quad 22 \quad 18$

$\begin{array}{lll}32 & 33 & 28\end{array}$

$\begin{array}{lll}14 & 17 & 17\end{array}$

$\begin{array}{lll}6 & 9 & 9\end{array}$

$\begin{array}{lll}5 & 6 & 9\end{array}$

$\begin{array}{lll}1 & 3 & 7\end{array}$

$\begin{array}{lll}1 & 2 & 4\end{array}$

$0 \quad 1$

\section{4 0 8

F1 = Control formulation; F2 = Formulation with 30\% whole soybean flour; F3 = Formulation with 50\% whole soybean flour;

F4 = Formulation with $70 \%$ whole soybean flour. 


\section{FIGURE 2}

Correlations between the data of each consumer acceptance and the first two principal components and dispersion of potato bread formulations in relation to acceptance.

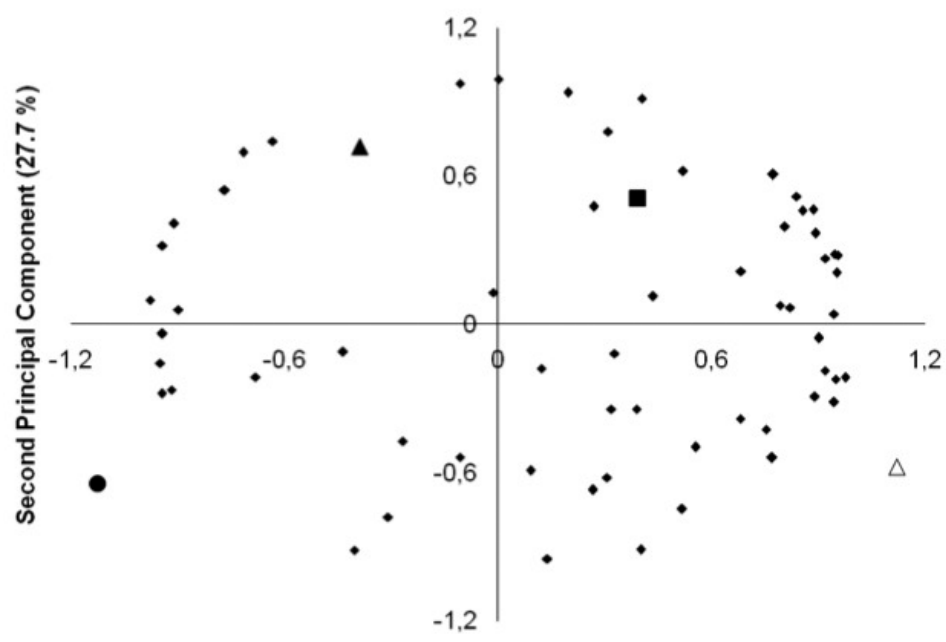

First Principal Component (51\%)

$\triangle \mathrm{F} 1 \boldsymbol{\mathrm { a }} 2 \Delta \mathrm{F} 3 \bullet \mathrm{F} 4$

F1 = Control formulation; F2 = Formulation with $30 \%$ whole soybean flour; F3 = Formulation with $50 \%$ whole soybean flour; F4 = Formulation with $70 \%$ whole soybean flour.

\section{FIGURE 3}

Correlation of instrumental texture parameters and consumer with the principal components.

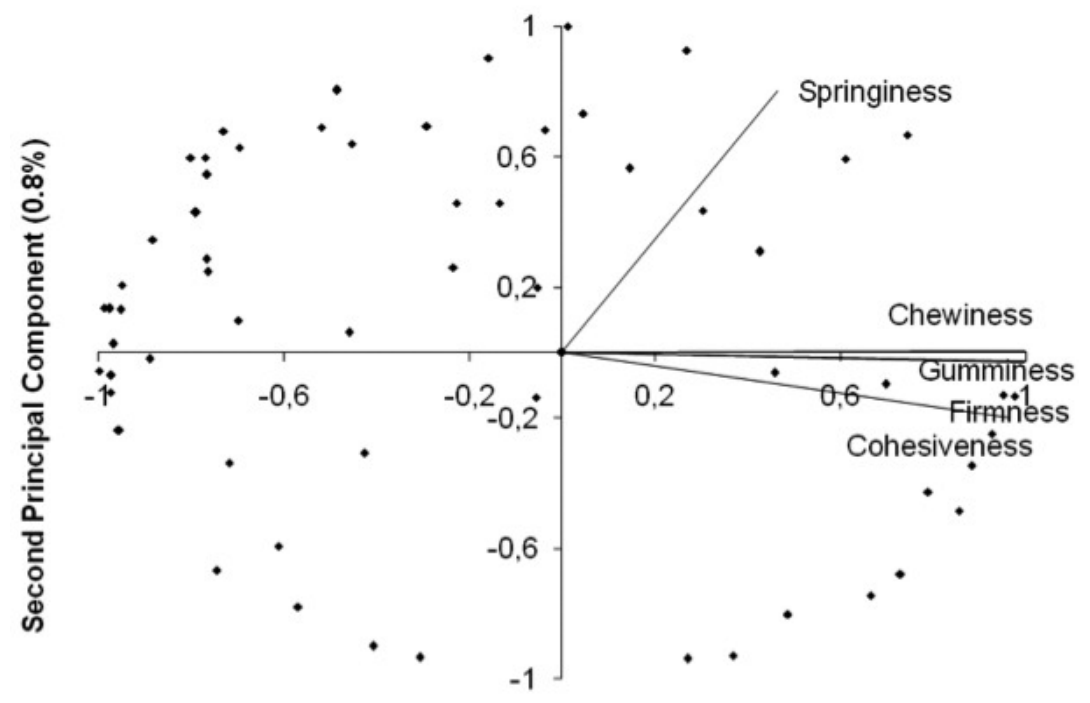

First Principal Component (98.7\%) 
variation in data, being sufficient to establish the correlation of texture attributes and consumer response. With the exception of springiness, the other texture parameters were positively correlated $(p<0.05)$ with the first principal component, while most consumer responses were negatively correlated.

\section{DISCUSSION}

The addition of up to $50 \%$ of whole soybean flour did not affect firmness, cohesiveness, gumminess and chewiness of the potato breads. However, the formulation with $70 \%$ whole soybean flour presented higher intensity of these parameters. The texture change of potato breads can be explained by the low starch content and absence of the gluten protein in the soybean $(15,26)$.

All the formulations with soybean flour presented a concentration of protein higher than the control. Corroborating this data, Justo et al. (1) found higher protein levels in whole breads with $10 \%$ and $17 \%$ soybean flour compared to standard whole bread. Similarly, Dantas et. al. (2) found higher protein levels in four formulations of sweet breads with 50 $\%$ soybean flour.

Philippi (27) classifies foods as a "source" of a nutrient if they meet from 5 to $10 \%$ of the Dietary Reference Intake (DRI), as a "good source" if they meet from 10 to $20 \%$ of the DRI, and as an "excellent source" if they meet more of $20 \%$ of the DRI. Considering the average DRI (28) for adult women and men, with ages between 19 and 50 years old, and the serving size of $50 \mathrm{~g}$ indicated by the legislation (29), the formulation with $30 \%$ whole soybean flour was considered a "source" of protein, while the formulations with $50 \%$ and $70 \%$ were classified as "goods sources." It has been shown in Brasil (30) that daily consumption of at least $25 \mathrm{~g}$ of soybean protein, associated with a balanced diet and healthy lifestyle, can help to reduce cholesterol. It is noteworthy that the soybean used in the preparation of flour for the potato breads presented an amino acid balance better that the conventional soybean, not being deficient in methionine, cysteine and tryptophan (31). Therefore, the protein of the whole soybean flour of cultivar UFVTN 105AP is more nutritionally adequate in relation to conventional flours and may thereby provide greater benefit to consumer health through fortified breads.

The formulations supplemented with whole soybean flour were good sources of dietary fiber (27) and are considered whole products that may promote healthy intestinal function (30). Similarly, Justo et al. (1) found higher levels of crude fiber in whole breads with added soybean, flaxseed, and chia flours in relation to standard whole wheat bread.

The increase in moisture in potato breads may be due to higher capacity for water retention by the dough with a higher protein concentration (15). The concentration of lipids in the various formulations did not differ because the oil contents were adjusted according to the lipid content of the whole soybean flour. The reduction in carbohydrate content contributed to an average decrease of $6 \%$ in the caloric value of each formulation with whole soybean flour.

An increase in mineral content occurred in the formulations according to soybean concentration (10). The formulations with whole soybean flour were classified as excellent sources of iron and manganese. Formulations containing 50 $\%$ and $70 \%$ of whole soybean flour were considered goods sources of zinc and magnesium while that containing $30 \%$ was a good source of zinc and a source of magnesium. In relation to copper and phosphorus, the potato breads with
$30 \%$ and $50 \%$ whole soybean flour were rated as goods sources and the formulation with $70 \%$ was an excellent source. All formulations with whole soybean flour were considered sources of potassium. The potato breads, although considered a good source of sodium, represented no more than $14 \%$ of the DRI in a serving size of $50 \mathrm{~g}(28,29)$. The fortified breads are, therefore, a good option to consumers seeking a good source of nutrients and recommended amount of sodium that can help to control sodium intake and decrease the risks of cardiovascular diseases.

The addition of whole soybean flour to potato breads increased the contents of minerals with antioxidant effects, such as zinc, manganese and copper, giving these foods the potential to prevent several non-communicable diseases (32). Moreover, calcium levels increased with increasing concentration of whole soybean flour, which makes these products a good alternative for increasing calcium intake, helping to prevent bone disease (33).

The four formulations were classified as goods sources of $\omega-6$ and $\omega-3$ fatty acids (27) in a serving size of $50 \mathrm{~g}$ (29) and the ratio of these two fatty acids was within the range recommended by the IOM (28). Hence, potato breads may contribute to the recommended intake of $\omega-6$ and $\omega-3$ and offer a strategy to address the high $\omega-6 / \omega-3$ ratio characteristic of the Western diet (34).

The concentration of whole soybean flour added to the formulations affects their overall acceptance; the acceptance was lower as the addition of whole soybean flour increased. However, all the formulations were well accepted by consumers. This outcome was likely impacted by the use of soybeans without lipoxygenases. Vasconcelos et al. (6) also found lower acceptance with an increase of the addition of soybean flour, but the concentrations used were much smaller than in this study. Additionally, Ivanovski (3) evaluated breads with $20 \%$ soybean flour and found lower scores of acceptance for these breads in relation to control, probably impacted by the use of the conventional soybean.

Unlike this study, Vasconcelos et al. (6) found percentages of the intention to purchase $44 \%, 83 \%$ and $78 \%$ lower than observed for the control. This was probably related to minimal acceptance of taste and appearance of the breads.

The analysis of correlation between the attributes of texture and the acceptance indicated that the highest values of firmness, cohesiveness, gumminess and chewiness negatively affect the acceptance of potato breads. Therefore, the instrumental texture parameters were important tools for predicting acceptance of newly developed products.

\section{CONCLUSION}

The incorporation of whole soybean flour in the preparation of potato bread contributed to an increase the nutritional value and added functional features to the food, since soybean is rich in nutrients and has functional nutritive properties.

The acceptance of products to which whole soybean flour had been added was influenced by their texture, since the samples with minimal firmness, cohesiveness, gumminess and chewiness were those most positively accepted.

Considering the physicochemical and sensory characteristics observed in this study, the most appropriate formulation for future use contained 30\% whole soybean flour. Thus, substitution of refined wheat flour by whole soybean flour is a viable alternative for the preparation of bakery products with the potential to reduce risk of several non-communicable diseases while maintaining sensory and physicochemical quality. 


\section{RESUMO}

O objetivo deste trabalho foi investigar os efeitos da fortificação de pães de batata com farinha integral de soja sobre as propriedades físico-químicas e sensoriais. Foram desenvolvidas as formulações controle e contendo 30\%, 50\% e $70 \%$ de farinha de soja. A dureza, coesividade, gomosidade e mastigabilidade dos pães aumentaram com a farinha integral de soja. Os teores de proteína, fibra alimentar e dos minerais cálcio, zinco, magnésio, cobre e fósforo foram maiores em função do aumento da concentração de farinha integral de soja, enquanto o perfil de lipídios não foi alterado. O Mapa de Preferência Interno indicou maior aceitação das formulações controle e com 30\% de farinha integral de soja. Esses resultados foram correlacionados à textura das formulações e revelaram que a maior dureza afetou negativamente sua aceitação. Conclui-se que a formulação com 30\% foi a melhor opção em relação aos parâmetros físico-químicos e sensoriais, o que torna a substituição das farinhas alternativa viável para elaboração de produtos de panificação fortificados e com qualidade físico-química e sensorial.

Palavras chave: ingredientes funcionais; composição química; aceitação sensorial; Mapa de Preferência Interno; propriedades físico-químicas.

\section{REFERENCES}

1. Justo MB, Alfaro ADC, Aguilar EC, Wrobel K, Guzmán A, Sierra ZG, et al. Desarrollo de pan integral con soya, chía, linaza y ácido fólico como alimento funcional para la mujer. Arch Latinoam Nutr 2007; 57(1):78-84.

2. Dantas MIS, Andrade GF, Piovesan, ND, Martino HSD. Farinhas mistas de trigo e de soja agregam valor nutricional e sensorial em pães. Rev Inst Adolfo Lutz 2009; 68(2):209-14.

3. Ivanovski B, Seetharaman K, Duizer LM. Development of Soy-Based Bread with Acceptable Sensory Properties. J Food Sci 2012; 71(1):71-6.

4. Brasil. Ministério da Saúde. Agência Nacional de Vigilância Sanitária. ANVISA. Regulamento técnico para produtos de cereais, amidos, farinhas e farelos. Resolução RDC $n^{\circ} 263$ de 22 de setembro de 2005. Diário Oficial [da] República Federativa do Brasil, Poder Executivo, Brasília, DF.

5. Battochio JR, Cardoso JMP, Kikuchi M, Macchione $M$, Modolo JS, Paixão AL, et al. Perfil sensorial de pão de forma integral. Ciênc Tecnol Aliment 2006; 26(2): 428-33.

6. Vasconcelos AC, Pontes DF, Garruti DS, Silva APV. Processamento e aceitabilidade de pães de forma a partir de ingredientes funcionais: farinha de soja e fibra alimentar. Aliment Nutr 2006; 17(1):43-9.

7. Schmile M, Silva, LH, Costa PFP, Rodrigues RS, Chang YK. Influência da adição de farinha integral de aveia flocos de aveia e isolado proteico de soja na qualidade tecnológica de bolo inglês. B. CEPPA 2011; 29(1): 71-82.

8. Goméz M, Moraleja A, Oliete B, Ruiz E, Caballero PA. Effect of fibre size on the quality of fibre-enriched layer cakes. LWT - Food Sci Technol 2010; 43: 33-8.

9. Ramos NC, Piemolini-Barreto LT, Sandri IG. Elaboração de pré-mistura para bolo sem glúten. Aliment Nutr 2012; 23(1): 33-8.

10. Esteves EA, Martino HSD, Oliveira FCE, Bressan J, Costa $N M B$. Chemical composition of a soybean cultivar lacking lipoxygenases (LOX2 and LOX3). Food Chem 2010; 122:238-42.

11. Ali AA, Velasquez MT, Hansen CT, Mohamed Al, Bhathena SJ. Modulation of carbohydrate metabolism and peptide hormones by soybean isoflavones and probiotics in obesity and diabetes. J Nutr Biochem 2005; 16:693-9.

12. Song $Y$, Paik HY, Joung $H$. Soybean and soy isoflavone intake indicate a positive change in bone mineral density for 2 years in young Korean women. Nutr Res 2008, 28: 25-30.

13. Barreiros ALBS, David JM, David JP. Estresse oxidativo: relação entre geração de espécies reativas e defesa do organismo. Quím Nova 2006; 29(1):113-23.

14. Martino HSD, Carvalho AW, Silva CO, Dantas MIS, Natal $D I G$, Ribeiro SMR, et al. The soybean hull flour of heattreated grains does not affect iron bioavailability in rats. Arch Latinoam Nutr 2011, 61(2): 135-42.

15. El-Dash A, Cabral LC, Germani R. Tecnologia de farinhas mistas: uso de farinhas mistas de trigo e soja na produção de pães, vol 3, EMBRAPA-SPI, Brasília, 1994.

16. Güemes-Vera N, Totosaus A, Hernandez JF, Soto S, Bolaños ENA. Propiedades de textura de masa y pan dulce tipo "concha" fortificados con proteínas de suero de leche. Ciênc Tecnol Aliment 2009; 29(1):70-5.

17. Association of Official Analytical Chemists. Official Methods of Analysis of the AOAC. 2th ed. Maryland, 1997.

18. Association of Official Analytical Chemists. Official Methods of Analysis of the AOAC. 16th ed. Washington, D.C., 2002.

19. Brasil. Ministério da Saúde. Agência Nacional de Vigilância Sanitária. ANVISA. Regulamento técnico para rotulagem obrigatória de alimentos e bebidas embalados. Resolução RDC $n^{\circ} 40$ de 21 de março de 2001. Diário Oficial [da] República Federativa do Brasil, Poder Executivo, Brasília, $D F$.

20. Gomes $J C$, Silva MHL, Silva CO. Análise de Alimentos, $2^{a}$ ed. revista e atualizada, FUNARBE, Viçosa, 2003.

21. Folch L, Lees M, Slaon-Stanley GN. A simple method for the isolation and purification of total lipids from animal tissues. J Biol Chem 1957; 226:497-509.

22. Hartmann L, Lago BCA. Rapid preparation of fatty acid methyl esters from lipids. Lab Practices 1973; 22:475-7.

23. Reis RC, Regazzi AJ, Carneiro JCS, Minim VPR. Mapa de preferência. In: Minim VPR, editor. Análise sensorial: Estudo com consumidores, Viçosa, MG, UFV, 2006. p. 13-50.

24. Macfie HJH, Thomson DMH. Preference mapping and multidimensional scaling. In: Piggot $J R$, editor. Sensory Analysis of Foods, $2^{a}$ ed, London, Elsevier, 1988. p. 389.

25. Carneiro JCS, Minim VPR, Souza Júnior MM, Carneiro JES, Araújo GAA. Perfil sensorial e aceitabilidade de cultivares de feijão (Phaseolus vulgaris L.). Ciênc Tecnol Aliment 2005; 25(1):18-24.

26. Karr-Lilienthal LK, Kadzere CT, Grieshop CM, Farey Jr GC. Chemical and nutritional properties of soybean carbohydrates as related to nonruminants: A review. Livest Produc Sci 2005; 97:1-12.

27. Philippi ST. Pirâmide dos alimentos - Fundamentos básicos da Nutrição, Barueri, SP, Manole, 2008. p. 378.

28. Institute of Medicine of the Nacional Academies. IOM. The Dietary Reference Intakes: The essencial guide to nutrient requeriments., Washington, D.C. 2006.

29. Brasil. Ministério da Saúde. Agência Nacional de Vigilância Sanitária. ANVISA. Regulamento Técnico sobre Rotulagem Nutricional de Alimentos Embalados. Resolução RDC n'360 de 23 de dezembro de 2003. Diário Oficial [da] República Federativa do Brasil, Poder Executivo, Brasília, DF.

30. Brasil. Ministério da Saúde. Agência Nacional de Vigilância Sanitária. ANVISA. Alimentos com Alegações de Proprie- 
dades Funcionais e ou de Saúde, Novos Alimentos/Ingredientes, Substâncias Bioativas e Probióticos. Alimentos. Comissões e Grupos de Trabalho. Comissão Tecnocientífica de Assessoramento em Alimentos Funcionais e Novos Alimentos. Diário Oficial [da] República Federativa do Brasil, Poder Executivo, Brasília, DF. Atualizado em 11 de janeiro de 2005. VIII-Lista das Alegações Aprovadas.

31. Carvalho A. Biodisponibilidade de ferro e qualidade protéica do cultivar de soja UFVTN 105AP com elevado teor protéico. 2009. 99f. Dissertação (Mestrado em Ciência da Nu- trição) - Universidade Federal de Viçosa, Viçosa, MG, 2009.

32. Stipanuk MH. Biochemical, Physiological \& Molecular Aspects of Human Nutritions, $2^{a}$ ed, Philadelphia, W B Saunders Company, 2006.

33. Reinwald S, Weaver CM. Soy Components vs. Whole Soy: Are We Betting Our Bones on a Long Shot? J Nutr 2010; 140: 2312-7.

34. Simopoulos AP. The importance the omega-6/ omega-3 fatty acid ratio in cardiovascular disease and other chronic disease. Exp Biol Med 2008; 233: 674-88. 